\title{
Correction to: The Influence of a Xanthine-Catechin Chemical Matrix on in vitro Macrophage-Activation Triggered by Antipsychotic Ziprasidone
}

\author{
Thiago Duarte, ${ }^{1}$ Fernanda Barbisan, ${ }^{2,3,7}$ Beatriz Sadigurski Nunes da Cunha, ${ }^{3}$ \\ Verônica Farina Azzolin, ${ }^{2}$ Bárbara Osmarin Turra, ${ }^{3}$ Marta Maria Medeiros Frescura Duarte, ${ }^{4}$ \\ Ivo Emilio da Cruz Jung, ${ }^{1}$ Euler Esteves Ribeiro, ${ }^{5}$ Pedro Antônio do Prado-Lima, 6 and \\ Ivana Beatrice Mânica da Cruz ${ }^{1,2}$
}

\author{
Correction to: Inflammation \\ https://doi.org/10.1007/s10753-018-0946-9
}

\begin{abstract}
After publication of our article it came to our attention that it contains a number of errors with regard to the citations. The details are provided below:

In Background section, 3rd paragraph: the correct citation is reference [8].

4th paragraph: "This is the case of chemical matrix present in beverages, such as green and black tea [8], yerba mate [9] and guaraná $[10,11]$ " should be "This is the case of
\end{abstract}

The online version of the original article can be found at https://oi.org/ 10.1007/s10753-018-0946-9

${ }^{1}$ Postgraduate Program in Pharmacology, Federal University of Santa Maria (UFSM), Santa Maria, RS, Brazil

${ }^{2}$ Postgraduate Program of Gerontology, Federal University of Santa Maria (UFSM), Santa Maria, RS, Brazil

${ }^{3}$ Biogenomic Laboratory, Center of Health Sciences, Federal University of Santa Maria (UFSM), Roraima Avenue 1000, Building 19, Chamber 3102, Santa Maria, RS, Brazil

${ }^{4}$ Center of Health Sciences, Lutheran University of Brazil (ULBRA), Santa Maria, RS, Brazil

${ }^{5}$ Foundation Open University of the Third Age, Manaus, AM, Brazil

${ }^{6}$ Brain Institute, Catholic University of Rio Grande do Sul, Porto Alegre, RS, Brazil

${ }^{7}$ To whom correspondence should be addressed at Biogenomic Laboratory, Center of Health Sciences, Federal University of Santa Maria (UFSM), Roraima Avenue 1000, Building 19, Chamber 3102, Santa Maria, RS, Brazil. E-mail: fernandabarbisan@gmail.com chemical matrix present in beverages, such as in some teas [9], yerba mate [10] and guaraná [11, 12]."

In the sentence: "Guaraná powder is broadly used to produce energetic beverages in the world $[12,13]$. Previous in vivo and in vitro studies have described that guaraná extract could have some antioxidant $[13,14]$ and antiinflammatory effects [13-16]" should be "Guaraná powder is broadly used to produce energetic beverages around the world $[12,13]$. Previous in vivo and in vitro studies have indicated that guaraná extract could have some antioxidant $[11,14]$ and anti-inflammatory effects [15-16]."

The former reference [13] (Pandiaraj P, Gnavavelbabu A, Saravanan $\mathrm{P}$. Synthesis of $\mathrm{CuO}$ nanofluids and analysis of its increased effective thermal conductivity for flat plate heat pipe. International Journal of ChemTech Research. 2015; 8(4):1972) should be removed and replaced with the reference [15] (Higgins JP, Kavita B, Deuster PA, Shearer J. Energy Drinks: A Contemporary Issues Paper. Current Sports Medicine Report. 2018; 17:65-72).

In Methods section, Bittencourt et al. [10] should be Bittencourt et al. [11].

In the sentence: "A colorimetric produce measure at $540 \mathrm{~nm}$ is obtained from this reaction that is proportional 
to the NO level present in the sample [18]" the correct reference is: Tatsch E, Bochi GV, Pereira Rda S, Kober H, Agertt VA, de Campos MM, Gomes P, Duarte MM, Moresco RN. 2011. A simple and inexpensive automated technique for measurement of serum nitrite/nitrate. Clin Biochem 44:348-350.

In the sentence: "Modulation of cytokine gene expression was conducted here by qRT-PCR analysis using a similar approach to that described by Jung et al. [20]" the correct reference is: da Cruz Jung, I.E., A.K. Machado, I.B.M. Cruz, F. Barbisan, V.F. Azzolin, T. Duarte, M.M.F. Duarte, P.A.S. do Prado-Lima, G.V. Bochi, G. Scola, and R.N. Moresco. 2016. Haloperidol and Risperidone at high concentrations activate an in vitro inflammatory response of RAW 264.7 macrophage cells by induction of apoptosis and modification of cytokine levels. Psychopharmacology
233: 1715-1723. The following reference was incorrectly cited and should be removed from the text: Voiculescu, M., I. Ghiță, A. Segărceanu, I. Fulga, and O. Coman. 2014. Molecular and pharmacodynamic interactions between caffeine and the dopaminergic system. Journal of Medicine and Life 7 (Spec Iss 4): 30-38.

In Discussion section, The reference listed as [29] should instead be reference [30].

The reference listed as [30] should instead be reference [29].

The authors wish to apologize for these unintentional errors.

Publisher's Note Springer Nature remains neutral with regard to jurisdictional claims in published maps and institutional affiliations. 